\title{
Distribution of plexin and neuropilin $m R N A$ s in the cranium and brain stem of chick embryos
}

\author{
Ziaul Haque ${ }^{1,2}$, Qin Pu and Ruijin Huang ${ }^{2,3}$ \\ ${ }^{1}$ Department of Anatomy and Histology, Bangladesh Agricultural University, Mymensingh-2202, Bangladesh \\ ${ }^{2}$ Department of Neuroanatomy, Institute of Anatomy, University of Bonn, Germany \\ ${ }^{3}$ Department of Molecular Embryology, Institute of Anatomy and Cell Biology, Albert- Ludwig-University, Germany
}

\begin{abstract}
Semaphorins exert their effects in neuronal and non-neuronal processes by binding with receptors. Both in vitro and in vivo studies have shown that plexin-As (plexin-A1, plexin-A1 and plexin-A1) and neuropilins $(N p n-1$ and $N p n-2)$ are the binding moieties for class-III semaphorins. These receptors are expressed in a spatially and temporally discontinuous manner during organogenesis and central nervous system (CNS) development in vertebrates. However, the signaling receptors that accompany with the class-III semaphorins to mediate their actions are still poorly characterized. To assess their diverse roles in neural circuit formation, we analyzed the expression patterns of plexin-A1, plexin-A2, plexin- $A 4, N p n-1$ and $N p n-2$ in the head and brain stem of chick embryos. In developing eye, plexin-A1 expressed in the lens, whereas plexin- $A 2$ and $N p n-1$ in the periorbital mesenchyme. Plexin- $A 1$ also expressed throughout the otic vesicle but $N p n-1$ expressed only in the dorsal part. Among the analyzed plexins and neuropilins, only $N p n-2$ expression was detected in the branchial arches. $N p n-2$ and plexin- $A 4$ were also expressed in the trigeminal and vago-accessory ganglia. In the hindbrain, all analyzed plexins and neuropilins were expressed by the selective sets of dorsal- (dMNs) and ventral exiting motor neurons (vMNs) except plexin- $A 4$ (only dMNs). Interestingly, plexin- $A 2$ and $N p n-1$ were co-expressed by the similar sets of dMNs and vMNs (trochlear, trigeminal, abducens, glossopharyngeal, vago-accessory and hypoglossal nuclei). These expression findings suggest that plexins and neuropilins are involved in neurodevelopment of the cranial structures in chick embryos.
\end{abstract}

\section{Introduction}

The development of the cranium requires deployment of a variety of cell types to specific locations in the embryonic head. The migration of cells to these positions and their subsequent patterning give rise to specific structures, e.g. brain, branchial arches, eye, ear etc. The cranial motor neurons arise from the basal plate of neural tube. One subtype of motor neurons extends their axons through the dorsal root, hence, termed dorsal-exiting motor neurons (dMNs). The axons of the other subtype called ventral-exiting motor neurons (vMNs) follow the ventral trajectory [1]. Once in the periphery, their axons follow a well-defined trajectory to navigate to their final target tissues and hence, are classified as branchiomotor (bm), visceromotor (vm) and somatomotor ( $\mathrm{sm}$ ) neurons. While sm neurons (vMNs) avoid sensory ganglia, bm/vm neurons (dMNs) exit close to the incoming sensory fibers and typically invade nearby cranial sensory ganglia [2].

Developing axons are navigated to their targets by binding of guidance molecules to receptors on the growth cone plasma membrane leads to the activation of intracellular signaling cascades. This results in dynamic change in the cytoskeleton and subsequent directional axon extension and target recognition [3]. Biochemical and genetic studies have revealed a variety of families of axon guidance molecules, including netrins, slits, semaphorins and ephrins [4]. The semaphorins exert their effects by binding with signal transducing plexins and ligand binding neuropilins (Npn-1 and Npn-2). Plexins are a family of transmembrane proteins that are distributed widely in both vertebrates and invertebrates [5]. Neuropilins are cell surface glycoproteins, initially described by Fujisawa and colleagues as an orphan receptor expressed in the tadpole neuropil [6]. During a search for other semaphorin receptors, a neuropilin-1 related molecule, $N p n-2$, was identified $[7,8]$.
Neither Npn-1 nor Npn-2 is able to convey semaphorin signals on their own [9] rather they form complexes with plexins [8,10-12]. Plexins are subdivided into 4 subclasses (A, B, C \& D) based on the structural criteria. The largest subfamily is the plexin- $A$ with four members (A1, A2, A3 \& A4), followed by the plexin- $B$ subfamily with three members (B1, B2 \& B3). Subfamilies C and D contain only one member each (C1 and D1). In the chicken genome only seven plexins (plexin- $A 1,-A 2$, $-A 4,-B 1,-B 2,-C 1 \&-D 1$ ) are found in contrast to mammals, where nine plexins have been identified [13].

Plexin-As are the best characterized among plexins. They are shown to mediate homophilic cell-cell adhesion in a calcium-dependent manner [14]. Furthermore, they are shown to mediate effects of membrane-bound class-6 semaphorins in a neuropilin-independent manner $[15,16]$. An interaction of plexin-B1 with Sema4D has been described, but little is known about the role of plexin-Bs in vivo $[17,18]$. Plexin-C1 is demonstrated to interact with Sema7A [19], although the only functional study available to date indicates Integrins rather than plexin-C1 as the function-mediating receptor for Sema7A [20]. Plexin-D1 finally is linked to the development of the heart and the vascular system consistent with its predominant expression in endothelial cells [21-23].

*Correspondence to: ZProf. Dr. med. Ruijin Huang, Department of Neuroanatomy, Institute of Anatomy, University of Bonn, Nussallee 10, 53115 Bonn, German, Tel: +49-0228-735618, Fax: +49-0228-733346; E-mail: ruijin.huang@uni-bonn.de

Key words: plexin, neuropilin, cranium, brain stem, chick embryos

Received: February 01, 2016; Accepted: February 11, 2016; Published: February 15,2016 
Despite the fact that plexin-As and neuropilins are involved in the formation of neuronal circuits, the temporal changes of their expression patterns during central nervous system development have not been analyzed in detail. For a better understanding of the diverse roles of plexin-As and neuropilins, we decided to assess their expression patterns in chick embryos. Here, we have analyzed the expression of plexin-As (plexin-A1, -A2, and -A4) and neuropilins (Npn-1 and Npn2) in the embryonic head. We have also focused on their expression by cranial motor neurons in the brain stem, which settle down into certain cranial nuclei, innervating the extraocular muscles, branchial arch derived muscles and tongue muscles.

\section{Materials and methods}

\section{Chick embryos}

Fertile White Leghorn chicken (Gallus gallus domesticus) eggs were obtained from the farm maintained by the Institute of Animal Science, University of Bonn, Germany. Eggs were incubated in a humidified (80\%) atmosphere at $37.8^{\circ} \mathrm{C}$ for the desired length of time and staged [24]. The embryos were fixed by $4 \%$ PFA in PBS or Dent's fixative for four hours to overnight at $4^{\circ} \mathrm{C}$. The hindbrains were opened dorsally along the roof plates and dissected free from the rest of the brain and the surrounding mesenchyme.

\section{Digoxigenin-labelled RNA probe synthesis}

Digoxigenin labeled sense and anti-sense RNA probes for the chick plexin-As (plexin-A1, plexin-A2 and plexin-A4) and neuropilins (Npn1 and $N p n-2)$ were synthesized from the template plasmids provided by Esther T Stoeckli, Institute of Zoology, University of Zurich, Switzerland and Gera Neufeld, Israel Institute of Technology, Israel, respectively. In brief, $1 \mu \mathrm{g} / \mu \mathrm{l}$ of linear DNA was suspended by RNAse free water. The followings were added to $20 \mu \mathrm{l}$ of solution: $2 \mu \mathrm{l}$ of $10 \mathrm{X}$ transcription buffer, $2 \mu$ l DIG-RNA labeling mix, $2 \mu$ RNA polymerase, and $0.5 \mu \mathrm{l}$ RNAse-Inhibitor. Sample was mixed and incubated at either $37^{\circ} \mathrm{C}(\mathrm{T} 3$ or $\mathrm{T} 7)$ or $42^{\circ} \mathrm{C}(\mathrm{Sp} 6)$ for at least 2 hours. The reaction was stopped by adding $0.5 \mu \mathrm{l}$ of $0.5 \mathrm{M}$ EDTA ( $\mathrm{pH}$ 8.0). Thereafter, $2.4 \mu \mathrm{l}$ of $4 \mathrm{M} \mathrm{LiCl}$ and $75 \mu \mathrm{l}$ of $100 \%$ cold ethanol were added and incubated overnight at $-20^{\circ} \mathrm{C}$. The solution was centrifuged at $130000 \mathrm{rpm}$ for 20 min. The fluid was removed carefully from the pellet and added $500 \mu \mathrm{l}$ of $70 \%$ cold ethanol. Then the solution was centrifuged again at 13000 $\mathrm{rpm}$ for $10 \mathrm{~min}$. The ethanol was removed from the pellet and dried at 37C (3-5 min). $50 \mu \mathrm{l}$ of RNAse free water and $0.5 \mu \mathrm{l}$ of RNAse-inhibitor were added to the pellet at $37^{\circ} \mathrm{C}$ for $20 \mathrm{~min}$. The probe concentration was measured by Dot-blot technique. A concentration of 50-100 ng/ $\mathrm{l}$ of probe was used for in situ hybridization.

\section{In situ hybridization}

In situ hybridization was performed by modified protocol as described by [25]. Briefly, the embryos were washed 2 times (5 min each) in PBT at room temperature (RT) with gentle rocking. They were subjected to bleach with 6\% hydrogen peroxide in PBT for $1 \mathrm{hr}$, followed by washing twice for $5 \mathrm{~min}$ with PBT. The embryos were treated with proteinase-K in PBT $(10 \mu \mathrm{g} / \mathrm{ml})$ for up to $10 \mathrm{~min}$ at RT. After rinsing carefully with PBT they were immediately post-fixed in $4 \%$ buffered formaldehyde for $30 \mathrm{~min}$ at RT. Then washed twice for $5 \mathrm{~min}$ with PBT at RT and placed the embryos in a mix of PBT: hybridization buffer $(1: 1)$ at RT and allowed them to be settled down at the bottom of the vials. This step was repeated by using hybridization buffer. The hybridization buffer was replaced with fresh buffer and incubated at $65^{\circ} \mathrm{C}$ for $1 \mathrm{hr}$. It was followed by hybridization with hybridization buffer-probe mix
$(0.05-0.1 \mu \mathrm{g} / \mathrm{ml})$. The hybridization mix was pre-warmed and the embryos were incubated with hybridization mix overnight at $65^{\circ} \mathrm{C}$. They were allowed for post-hybridization washes (2X SSC/CHAPS and $0.2 \mathrm{X} \mathrm{SSC/CHAPS,} 20 \mathrm{~min}$ each at $65^{\circ} \mathrm{C}$ ) followed by KTBT buffer at RT for $10 \mathrm{~min}$. The embryos were blocked by $10 \%$ FCS in KTBT for 4 hrs at RT and incubated with Anti-DIG-AP/ KTBT (1:2000) overnight at $4^{\circ} \mathrm{C}$. Then washed 6 times in KTBT ( 1 hour each) followed by two washes in AP buffer ( 20 min each) at RT. Finally, the antibody was detected by using NBT/BCIP in AP $(20 \mu \mathrm{l} / \mathrm{ml})$.

\section{Photographic documentation and data analysis}

Samples were photographed by using Nikon digital camera DXM1200C connected to a Nikon SM21500 fluorescence microscope. In all cases, images were assembled and annotated using Adobe Photoshop CS3.

\section{Results and discussion}

To understand the function of semaphorins, a proper assessment of the expression of receptors in a given species or system is prerequisite. The chick embryo is an attractive model system to study the role of semaphorins and their receptors, given its accessibility and the potential for functional analysis. We analyzed the expression of plexin-As (plexin-A1, plexin-A2 and plexin-A4) and neuropilins (Npn-1 and Npn2) found in the chicken genome during embryonic development of head and brain stem. We analyzed the expression patterns of plexin-As (plexin-A1, plexin-A2 and plexin-A4) and neuropilins ( $N p n-1$ and Npn2 ) in chick embryos by in-situ hybridization (whole-mount and flatmount) using relevant $m R N A$ probes. Our results showed expression in orbit, otic vesicle, branchial arches, cranial ganglia and hindbrain.

\section{Orbital expression}

Periorbital mesenchyme of neural crest origin accumulates and later gives rise to the iris, sclera, and cornea [26]. We observed that both plexin-A2 and Npn-1 expressed in the periorbital mesenchyme (Figure), supporting their co-operative roles in eyeball development. Besides, plexin-A1 expression was found in the lens (Figure). The lens has been shown to be the source of a chemorepellent activity toward retina [27,28]. $N p n-1$ and $N p n-2$ signaling are required for proper innervations of the mouse cornea [29]. Knockdown of plexin-A1 or plexin- $A 2$ result in striking and reproducible axon guidance defects of oculomotor nerve [30]. These observations together with our data suggest the comprehensive role of plexin-A1, plexin- $A 2$ and $N p n-1$ in development and innervations of eye.

\section{Expression in the otic vesicle}

The otic vesicle is an intermediate step in inner ear development between the initial formation of the otic placode and the differentiation into vestibular and auditory structures. The dorsolateral otic vesicle gives rise to the vestibular organ, whereas the ventromedial half forms the cochlear. Many genes that determine this differentiation are already localized to specific areas of the otic vesicle before any obvious morphologic changes are apparent [31,32]. We found expression of plexin- $A 1$ throughout the otic vesicle (Figure 1a), while restricted expression (dorsal) was evident for $\mathrm{Npn-1}$ (Figure1c). But plexin-A2, plexin- $A 4$ and $N p n$-2 did not express in the otic vesicle. The region of the otic vesicle expressing Npn-1 (Figure 1c) correlates with that expressing Dlx5 (Merlo et al., 2002). Mice lacking this transcription factor have dysmorphogenesis of the vestibular organ (Merlo et al., 2002). All these observations in the developing otic vesicle suggest that plexin- $A 1$ and $N p n-1$ play role in controlling the subsequent morphology of the 
vestibular and auditory derivatives or in their innervations.

\section{Branchial arch expression}

The branchial arches consist of a mesodermal core containing muscle precursor cells surrounded by a peripheral population of neural crest cells, which will give rise to skeletal and connective tissue [33,34]. We found expression of Npn-2 in the branchial arches (Figure 1e) supporting innervations of arch derived muscles. The bm/vm (dMNs) motor neurons in hindbrain innervate muscles differentiating within the branchial arches that derive from myogenic cells emigrating from the ventral edge of the cranial paraxial mesoderm [35,36]. A parallel situation exists in the case of precursors of the limb musculature that migrate from the ventrolateral edge of the trunk somites [37], implying that there might be some similarities between the neurons innervating these two types of muscles. However, limb-innervating motor neurons of the spinal cord expressed other LIM genes in addition to Islet-1. In particular, limb-innervating spinal motor neurons express LIM-1 [38], expression of which was not detected in any cranial motor neuron subpopulation. The sm cranial motor neuron groups that express the same repertoire of LIM genes (Islet-1 and Islet-2) innervate muscles that are derived either from the cranial paraxial mesoderm or from the prechordal plate mesoderm [35,36].

\section{Expression in the cranial ganglia}

Neural crest cells (NCCs) that do not invade the branchial arches generate cranial sensory ganglia [39]. $N p n-2$ is preferentially expressed in NCCs emigrating from $\mathrm{r} 2$ and giving rise to trigeminal ganglia [40] and it's signaling is essential for trigeminal ganglion condensation (Gammill et al., 2007). Neuropilins control cranial gangliogenesis and axon guidance through NCCs [41]. We found expression of plexin-A4 and Npn-2 in both ganglia and motor neurons (trigeminal and vago-accessory, Figure $1 \mathrm{c}$ and $1 \mathrm{e}$ ) supports their roles in trajectory of respective cranial nerves. This pairing could be responsible for the signal produced by the ganglion to direct the migration and outgrowth of the motor neuron cell bodies and their axons $[42,43]$.

\section{Hindbrain expression}

Differential regulation of the receptors that mediate chemoattraction or chemorepulsion by axon guidance molecules such as members of the semaphorin family could result in the characteristic location of motor nuclei and connectivity patterns [44-47]. The migration of motor neurons to their final destinations is a key process in the development of the nervous system. This process must be coordinated with the establishment of connectivity and requires differential responses of distinct neuronal compartments to the multitude of guidance cues in the environment.

Subpopulations of cranial motor neurons express different semaphorin receptors and make divergent decisions along their axonal trajectories. We analyzed the expression of chick plexin-As (plexin-A1, $-A 2$ and -A4) and neuropilins (Npn-1 and Npn-2) in the flat-mounted hindbrains of developing chick embryos (Figure 2a-2i). At HH 19, plexin-A1 was expressed longitudinally throughout the ventral region of neural tube. However, the expression was more prominent at the level of $\mathrm{r} 1$ and $\mathrm{r} 7-8$ (Figure 2a). The expression patterns of plexin-A2 and plexin- $A 4$ were found almost similar in the hindbrain (Figure $2 \mathrm{~d}$ and $2 \mathrm{~g}$ ). Both expressed into two longitudinal domains medially which were expanded gradually lateral from $\mathrm{r} 2-8$. Plexin- $A 4$ expression was much stronger at the level of r7-8 (Figure 2d) but r6-8 in case of plexin-A4 (Figure 2g), both of which became narrower close to
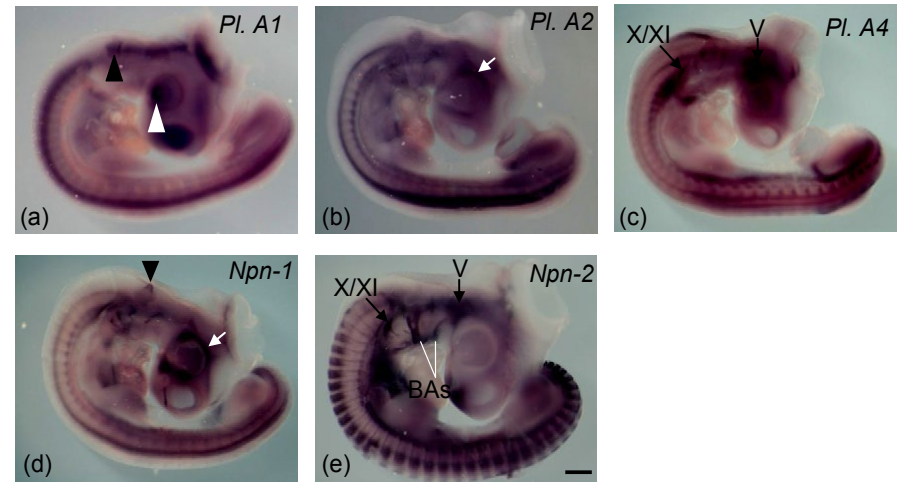

Figure 1. Plexin-As (-A1, $-A 2$, and $-A 4$ ) and neuropilins (Npn-1 and Npn-2) expression in the embryonic chick head and brain stem at stage 21 (a-e). Black and white arrow heads indicate expression in the otic vesicle ( $a$ and c) and lens (a), respectively. White arrows show expression in the periorbiatal mesenchyme (b and d) and black arrows in the cranial ganglia (c and e). $\mathrm{V}=$ trigeminal ganglia, $\mathrm{X} / \mathrm{XI}=$ vago-accessory ganglia and $\mathrm{BAs}=$ branchial arches. Scale bar in all imges $=250 \mu \mathrm{m}$.
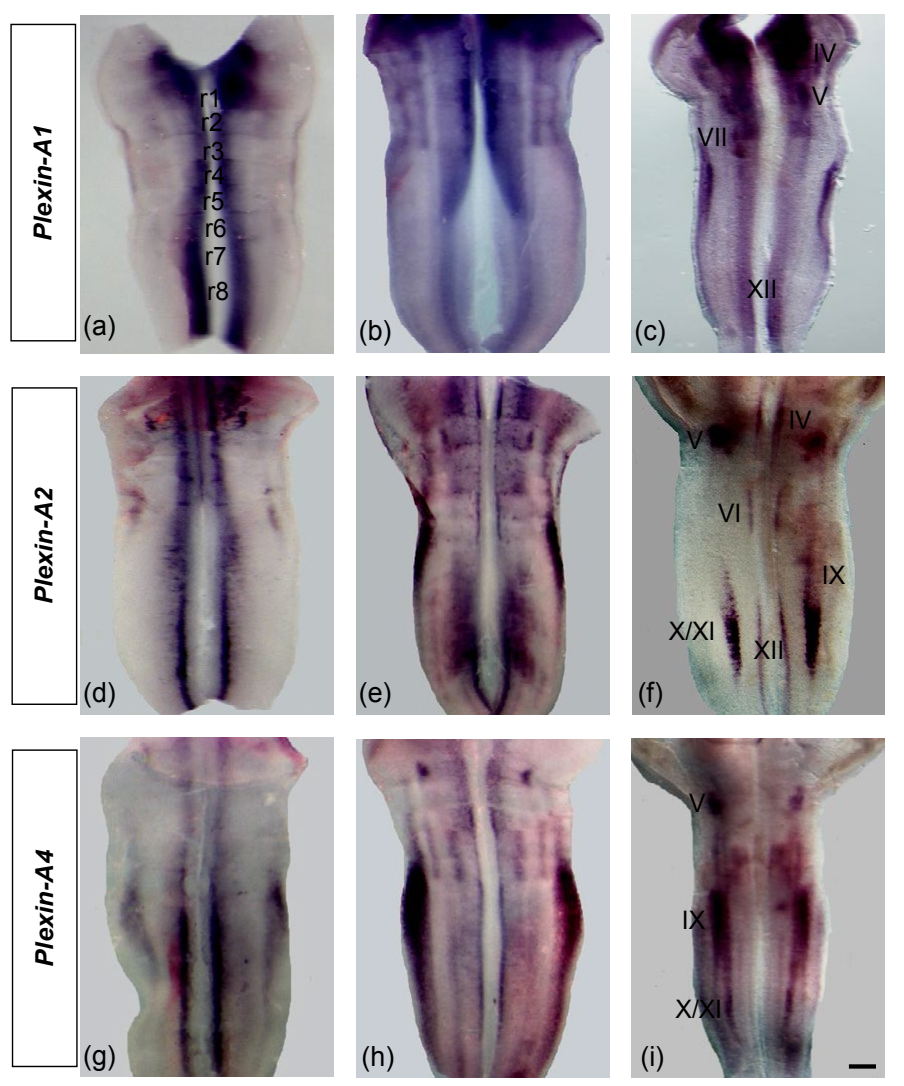

Figure 2. Expression of plexin- $A s$ ( $-A 1,-A 2$ and $-A 4)$ in the flat-mounted hindbrains (open book) of chick embryos (a-i). At HH 19, plexin- $A 1,-A 2$ and $-A 4$ expressions appear as two longitudinal stripes throughout the ventral neural tube (a, $d$ and g). At $\mathrm{HH} 23$, the expressions expand toward the prospective nuclei within the rhombomeric boundaries $(b$, $\mathrm{e}$ and $\mathrm{h}$ ). At $\mathrm{HH} 27$, plexin- $A 1,-A 2$ and $-A 4$ are expressed in the cranial nuclei (c, $\mathrm{f}$ and i) as marked by Roman numerical $(\mathrm{III}=$ occulomotor, $\mathrm{IV}=$ trochlear, $\mathrm{V}=$ trigeminal, $\mathrm{VI}=$ abducens, $\mathrm{VII}=$ facial, $\mathrm{IX}=$ glossopharyngeal, $\mathrm{X} / \mathrm{XI}=$ vago-accessory, $\mathrm{XII}=$ hypoglossal). Scale bar in all images $=200 \mu \mathrm{m}$.

the floor plate. At $\mathrm{HH} 23$, plexin- $A 1,-A 2$ and $-A 4$ expressions were expanded towards the prospective nuclei within the rhombomeres of hindbrain (Figure 2b, 2e and 2h). At $\mathrm{HH} 27$, we compared the expression patterns of these genes with the expression of motor neuron marker Islet-1 [48]. Our results showed that plexin-A1 expressed in the 
trochlear (vMNs), trigeminal (dMNs), facial (dMNs) and hypoglossal (vMNs) nuclei; plexin-A2 in the trochlear (vMNs), trigeminal (dMNs), abducens (vMNs), glossopharyngeal (dMNs), vago-accessory (dMNs) and hypoglossal (vMNs) nuclei and plexin-A4 only in dMNstrigeminal, glossopharyngeal and vago-accessory nuclei (Figure $2 \mathrm{c}, 2 \mathrm{f}$ and 2i). Our expression data for neuropilins demonstrated that both $N p n-1$ and Npn-2 expressed strongly at the level of $\mathrm{r} 1-2$ and $\mathrm{r} 7-8$ ( $\mathrm{HH}$ 19). However, Npn-2 expression was much stronger and extensive than Npn-1 (Figure 3a and 3d). The expressions were distributed towards the prospective nuclei within the rhombomeric boundaries of hindbrain at $\mathrm{HH} 23$ (Figure 3b and 3e). By HH 27, most cranial motor neurons migrate to their final positions in hindbrain [49]. Here, we compared the expression of these two genes ( $N p n-1$ and $N p n-2)$ with the expression of motor neuron marker Islet-1 [48]. We found that $N p n-1$ expressed in the trochlear (vMNs), trigeminal (dMNs), abducens (vMNs), glossopharyngeal (dMNs), vago-accessory (dMNs) and hypoglossal (vMNs) nuclei, whereas $N p n-2$ in trochlear (vMNs), trigeminal (dMNs), facial (dMNs), glossopharyngeal (dMNs), vagoaccessory (dMNs) and hypoglossal (vMNs) nuclei (Figure $3 \mathrm{c}$ and $3 \mathrm{f}$ ). These results show that plexin- $A 1$ and plexin- $A 2$ are expressed by both $\mathrm{dMNs}$ and vMNs but plexin- $A 4$ only by dMNs. Besides, $N p n-1$ and $N p n-2$ are expressed by both sets of hindbrain motor neurons (dMNs and vMNs).

The expression data in mouse and chick embryos suggested that the multimeric surface receptors for secreted class-III semaphorins are neuropilins and/or plexins [13,50,51]. In the mouse (E10.5-12.5), plexin-A2 was found in the roof plate and in interneurons of the ventral spinal cord but not in motor neurons of the trunk region [52]. Besides, Npn-2 is expressed very strongly in dorsal commissural neurons, ventral populations of motor neurons, and in the floor plate $[53,54]$. In chick, $N p n-2$ is expressed in the motor neuron pools but never expressed in the embryonic chicken floor plate and dorsal spinal cord at comparable stages [13]. In the chick lumbo-sacral spinal cord, premigratory motor neurons expressed plexin-A1, plexin-A2, Npn1 but not $N p n-2$ [13]. At the migratory stage, $N p n-2$ appeared to be expressed predominantly in a dorso-lateral subset of Islet1-positive cells, while plexin-A2 was scattered throughout the ventral horn [13]. [55], confirmed and extended the observation of [13]; showing dynamic patterns of expression of plexin-A2 and Npn-2. They reported both expressions in spinal motor neurons or their progenitors at premigratory stage which expressed in medial and lateral subsets of motor neurons at the migratory stage. We observed that plexins and neuropilins expressed in the ventral neural tube at early migratory stage of hindbrain development. At the late migrating stage, the expressions appear dorso-lateral along with persistent expression medially. After most of the cranial motor neurons find their final positions, their expressions appear into two domains giving rise to medial (vMNs) and lateral nuclei (dMNs). The medial nuclei located close to the floor plate, while lateral close to the rhombomeric boundaries. All plexins (except plexin-A4) and neuropilins (Npn-1 and Npn-2) were detected in both medial and lateral nuclei of chick hindbrain. Plexin-A2 expression was similar to Npn-1 in cranial nuclei. These combinatorial and differential expression patterns of plexin-As and neuropilins in the cranial nuclei suggest their roles in neural circuit formation for selective sets of cranial nerves during hindbrain development.

The differentiation of neuronal subtype (dMNs and vMNs) is controlled by the Phox and LIM homeodomain factors [56,57]. In this regard, it is interesting to note that glossopharyngeal (nIX) and vagus $(\mathrm{nX})$ nerves appear fused in Nkx2.9 null mice and the spinal accessory (nXI) motor neurons are unable to migrate to a dorso-lateral position and their axons are incapable of exiting the neural tube [58]. Our expression data showed that these cranial motor neurons (dMNs) strongly express plexin-A4 and Npn-2. This raises the possibilities that $N k \times 2.9$ acts to maintain the function of plexin-A4 and Npn-2 during axon guidance of dMNs in hindbrain. Loss of Nkx6.1, Nkx6.2 and Pax6 during somatic motor neuron development deletes abducens and hypoglossal motor neurons [59]. We found that plexin-A2 and Npn1 co-expressed in abducens and hypoglossal (vMNs) motor neurons. From this observation, it is probable that the action of plexin- $A 2$ and $N p n-1$ in axon guidance of abducens (nVI) and hypoglossal (nXII) nerves are regulated by $N k x 6$ and Pax 6 genes. The differentiation of the dMNs is required Phox2a/b expression [56]. Lhx3 and Lhx4 are important for the vMN differentiation and the formation of the medial motor column [57]. These reports are also correlated with our expression data suggesting that Phox and Lhx genes might control the function of plexins and neuropilins in axon guidance of dMNs and vMNs. Considering the available reports mentioned above together with our observations, we can say that selective function of plexins and Neuropilins is likely to be the result of the differential expression by motor neurons that mediate responses to diffusible and contactdependent signals. This expression might in turn be the consequence of the differential activation of transcription factors involved in axon guidance of cranial nerves.

In conclusion, the expression patterns of the plexins and neuropilins presented in the cranium and hindbrain will undoubtedly reveal further, more refined combinations of receptors for ligand localizations. The current study highlights several possible roles for plexins and neuropilins in directing early cranial development, particularly the patterning of early axon tracts but also the guidance of cell migration and morphologic changes. Further research can be conducted to explore their functional roles during head and brain development.

\section{Acknowledgments}

We thank Developmental Studies Hybridoma Bank, Iowa City, IA, USA for antibodies. We are also indebted to Dr. Michael Pankratz for valuable suggestions on this work. The technical support of Sandra Gräfe is much appreciated.

\section{Conflict of interests}

The authors declare that they have no competing interests.

\section{References}

1. Bravo-Ambrosio A, Kaprielian Z (2011) Crossing the border: molecular control of motor axon exit. Int J Mol Sci 12: 8539-8561. [Crossref]

2. Jacob J, Hacker A, Guthrie S (2001) Mechanisms and molecules in motor neuron specification and axon pathfinding. Bioessays 23: 582-595. [Crossref]

3. Huber AB, Kolodkin AL, Ginty DD, Cloutier JF (2003) Signaling at the growth cone: ligand-receptor complexes and the control of axon growth and guidance. Annu Rev Neurosci 26: 509-563. [Crossref]

4. Dickson BJ (2002) Molecular mechanisms of axon guidance. Science 298: 1959-1964. [Crossref]

5. Fujisawa $\mathrm{H}$ (2004) Discovery of semaphorin receptors, neuropilin and plexin, and their functions in neural development. J Neurobiol 59: 24-33. [Crossref]

6. Fujisawa H1 (2002) From the discovery of neuropilin to the determination of its adhesion sites. Adv Exp Med Biol 515: 1-12. [Crossref]

7. Chen H, Chédotal A, He Z, Goodman CS, Tessier-Lavigne M (1997) Neuropilin-2, a novel member of the neuropilin family, is a high affinity receptor for the semaphorins Sema E and Sema IV but not Sema III. Neuron 19: 547-559. [Crossref] 
8. Kolodkin AL, Levengood DV, Rowe EG, Tai YT, Giger RJ, et al. (1997) Neuropilin is a semaphorin III receptor. Cell 90: 753-762. [Crossref]

9. Feiner L, Koppel AM, Kobayashi H, Raper JA (1997) Secreted chick semaphorins bind recombinant neuropilin with similar affinities but bind different subsets of neurons in situ. Neuron 19: 539-545. [Crossref]

10. Giger RJ, Urquhart ER, Gillespie SK, Levengood DV, Ginty DD, et al. (1998) Neuropilin-2 is a receptor for semaphorin IV: insight into the structural basis of receptor function and specificity. Neuron 21: 1079-1092. [Crossref]

11. He Z, Tessier-Lavigne M (1997) Neuropilin is a receptor for the axonal chemorepellent Semaphorin III. Cell 90: 739-751. [Crossref]

12. Kitsukawa T, Shimizu M, Sanbo M, Hirata T, Taniguchi M, et al. (1997) Neuropilinsemaphorin III/D-mediated chemorepulsive signals play a crucial role in peripheral nerve projection in mice. Neuron 19: 995-1005. [Crossref]

13. Mauti O, Sadhu R, Gemayel J, Gesemann M, Stoeckli ET (2006) Expression patterns of plexins and neuropilins are consistent with cooperative and separate functions during neural development. BMC Dev Biol 6: 32. [Crossref]

14. Ohta K, Mizutani A, Kawakami A, Murakami Y, Kasuya Y, et al. (1995) Plexin: a novel neuronal cell surface molecule that mediates cell adhesion via a homophilic binding mechanism in the presence of calcium ions. Neuron 14: 1189-1199. [Crossref]

15. Suto F, Ito K, Uemura M, Shimizu M, Shinkawa Y, et al. (2005) Plexin-a4 mediates axon-repulsive activities of both secreted and transmembrane semaphorins and plays roles in nerve fiber guidance. $J$ Neurosci 25: 3628-3637. [Crossref]

16. Toyofuku T, Zhang H, Kumanogoh A, Takegahara N, Suto F, et al. (2004) Dual roles of Sema6D in cardiac morphogenesis through region-specific association of its receptor, Plexin-A1, with off-track and vascular endothelial growth factor receptor type 2. Genes \& Dev 18: 435-447. [Crossref]

17. Giordano S, Corso S, Conrotto P, Artigiani S, Gilestro G, et al. (2002) The semaphorin 4D receptor controls invasive growth by coupling with Met. Nat Cell Biol 4: 720-724. [Crossref]

18. Neufeld G, Shraga-Heled N, Lange T, Guttmann-Raviv N, Herzog Y, et al. (2005) Semaphorins in cancer. Front Biosci 10: 751-760. [Crossref]

19. Tamagnone L, Artigiani S, Chen H, He Z, Ming GI, et al. (1999) Plexins are a large family of receptors for transmembrane, secreted, and GPI-anchored semaphorins in vertebrates. Cell 99: 71-80. [Crossref]

20. Pasterkamp RJ, Peschon JJ, Spriggs MK, Kolodkin AL (2003) Semaphorin 7A promotes axon outgrowth through integrins and MAPKs. Nature 424: 398-405. [Crossref]

21. Gitler AD, Lu MM, Epstein JA (2004) PlexinD1 and semaphorin signaling are required in endothelial cells for cardiovascular development. Dev Cell 7: 107-116. [Crossref]

22. Torres-Vázquez J, Gitler AD, Fraser SD, Berk JD, Van N Pham, et al. (2004) Semaphorin-plexin signaling guides patterning of the developing vasculature. Dev Cell 7: 117-123. [Crossref]

23. Van Der Zwaag B, Hellemons AJ, Leenders WP, Burbach JPH, Brunner HG, Padberg GW, Van Bokhoven H (2002) PLEXIN-D1, a novel plexin family member, is expressed in vascular endothelium and the central nervous system during mouse embryogenesis. Dev Dyn 225: 336-343. [Crossref]

24. Hamburger V, Hamilton HL (1951) A series of normal stages in the development of the chick embryo. J Morphol 88: 49-92. [Crossref]

25. Wilkinson DG (1992) The theory and practice of in situ hybridization. In Situ Hybridisation: A Practical Approach 1-13.

26. Jean D, Ewan K, Gruss P (1998) Molecular regulators involved in vertebrate eye development. Mech Dev 76: 3-18. [Crossref]

27. Ohta K, Tannahill D, Yoshida K, Johnson AR, Cook GM, et al. (1999) Embryonic lens repels retinal ganglion cell axons. Dev Biol 211: 124-132. [Crossref]

28. Shepherd I, Luo Y, Raper JA, Chang S (1996) The distribution of collapsin-1 mRNA in the developing chick nervous system. Dev Biol 173: 185-199. [Crossref]

29. McKenna CC, Munjaal RP, Lwigale PY (2012) Distinct roles for neuropilin1 and neuropilin2 during mouse corneal innervation. PLoS One 7: e37175. [Crossref]

30. Ferrario JE, Baskaran P, Clark C, Hendry A, Lerner O, et al. (2012) Axon guidance in the developing ocular motor system and Duane retraction syndrome depends on Semaphorin signaling via alpha2-chimaerin. Proc Natl Acad Sci U S A 109: 1466914674. [Crossref]
31. Torres M, Giráldez F (1998) The development of the vertebrate inner ear. Mech Dev 71: 5-21. [Crossref]

32. Merlo GR, Paleari L, Mantero S, Zerega B, Adamska M, et al. (2002) The Dlx5 homeobox gene is essential for vestibular morphogenesis in the mouse embryo through a BMP4-mediated pathway. Dev Biol 248: 157-169. [Crossref]

33. Trainor PA, Tam P (1995) Cranial paraxial mesoderm and neural crest cells of the mouse embryo: co-distribution in the craniofacial mesenchyme but distinct segregation in branchial arches. Development 121: 2569-2582. [Crossref]

34. Hacker A, Guthrie S (1998) A distinct developmental programme for the crania paraxial mesoderm in the chick embryo. Development 125: 3461-3472. [Crossref]

35. Couly GF, Coltey PM, Le Douarin NM (1992) The developmental fate of the cephalic mesoderm in quail-chick chimeras. Development 114: 1-15. [Crossref]

36. Noden DM (1992) Vertebrate craniofacial development: novel approaches and new dilemmas. Curr Opin Genet Dev 2: 576-581. [Crossref]

37. Christ B, Jacob HJ, Jacob M, Brand B (1986) Principles of hand ontogenesis in man. Acta Morphol Neerl Scand 24: 249-268. [Crossref]

38. Tsuchida T, Ensini M, Morton SB, Baldassare M, Edlund T, et al. (1994) Topographic organization of embryonic motor neurons defined by expression of LIM homeobox genes. Cell 79: 957-970. [Crossref]

39. Baker C, Bronner-Fraser M, Le Douarin NM, Teillet M-A (1997) Early-and latemigrating cranial neural crest cell populations have equivalent developmental potential in vivo. Development 124: 3077-3087. [Crossref]

40. Lumb R, Wiszniak S, Kabbara S, Scherer M, Harvey N, et al. (2014) Neuropilins define distinct populations of neural crest cells. Neural Dev 9: 24. [Crossref]

41. Schwarz Q, Waimey KE, Golding M, Takamatsu H, Kumanogoh A, et al. (2008) Plexin A3 and plexin A4 convey semaphorin signals during facial nerve development. Dev Biol 324: 1-9. [Crossref]

42. Moody SA, Heaton MB (1983) Developmental relationships between trigeminal ganglia and trigeminal motoneurons in chick embryos. I. Ganglion development is necessary for motoneuron migration. J Comp Neurol 213: 327-343.

43. Moody SA, Heaton MB (1983) Developmental relationships between trigemina ganglia and trigeminal motoneurons in chick embryos. III. Ganglion perikarya direct motor axon growth in the periphery. J Comp Neurol 213: 350-364.

44. Adams RH, Betz H, Püschel AW (1996) A novel class of murine semaphorins with homology to thrombospondin is differentially expressed during early embryogenesis. Mech Dev 57: 33-45. [Crossref]

45. Luo Y1, Raible D, Raper JA (1993) Collapsin: a protein in brain that induces the collapse and paralysis of neuronal growth cones. Cell 75: 217-227. [Crossref]

46. Messersmith EK, Leonardo ED, Shatz CJ, Tessier-Lavigne M, Goodman CS, et al (1995) Semaphorin III can function as a selective chemorepellent to pattern sensory projections in the spinal cord. Neuron 14: 949-959. [Crossref]

47. Püschel AW, Adams RH, Betz H (1995) Murine semaphorin D/collapsin is a member of a diverse gene family and creates domains inhibitory for axonal extension. Neuron 14: 941-948. [Crossref]

48. Varela-Echavarría A, Pfaff SL, Guthrie S (1996) Differential expression of LIM homeobox genes among motor neuron subpopulations in the developing chick brain stem. Mol Cell Neurosci 8: 242-257. [Crossref]

49. Simon H, Guthrie S, Lumsden A (1994) Regulation of SC1/DM-GRASP during the migration of motor neurons in the chick embryo brain stem. J Neurobiol 25: 11291143. [Crossref]

50. Cohen S, Funkelstein L, Livet J, Rougon G, Henderson CE, et al. (2005) A semaphorin code defines subpopulations of spinal motor neurons during mouse development. Eur J Neurosci 21: 1767-1776. [Crossref]

51. Huber AB, Kania A, Tran TS, Gu C, De Marco Garcia N, et al. (2005) Distinct roles for secreted semaphorin signaling in spinal motor axon guidance. Neuron 48: 949-964. [Crossref]

52. Brown CB, Feiner L, Lu MM, Li J, Ma X, et al. (2001) PlexinA2 and semaphorin signaling during cardiac neural crest development. Development 128: 3071-3080. [Crossref]

53. Chen H, Bagri A, Zupicich JA, Zou Y, Stoeckli E, et al. (2000) Neuropilin-2 regulates the development of selective cranial and sensory nerves and hippocampal mossy fiber projections. Neuron 25: 43-56. [Crossref] 
54. Kawakami A, Kitsukawa T, Takagi S, Fujisawa H (1996) Developmentally regulated expression of a cell surface protein, neuropilin, in the mouse nervous system. $J$ Neurobiol 29: 1-17. [Crossref]

55. Bron R, Vermeren M, Kokot N, Andrews W, Little GE, et al. (2007) Boundary cap cells constrain spinal motor neuron somal migration at motor exit points by a semaphorinplexin mechanism. Neural Dev 2: 14674. [Crossref]

56. Hirsch MR, Glover JC, Dufour HD, Brunet JF, Goridis C (2007) Forced expression of Phox2 homeodomain transcription factors induces a branchio-visceromotor axonal phenotype. Dev Biol 303: 687-702. [Crossref]
57. Sharma K, Sheng HZ, Lettieri K, Li H, Karavanov A, et al. (1998) LIM homeodomain factors Lhx3 and Lhx4 assign subtype identities for motor neurons. Cell 95: 817-828. [Crossref]

58. Pabst O, Rummelies J, Winter B, Arnold HH (2003) Targeted disruption of the homeobox gene Nkx2.9 reveals a role in development of the spinal accessory nerve. Development 130: 1193-1202. [Crossref]

59. Ericson J, Rashbass P, Schedl A, Brenner-Morton S, Kawakami A, et al. (1997) Pax6 controls progenitor cell identity and neuronal fate in response to graded Shh signaling. Cell 90: 169-180. [Crossref]

Copyright: (C2016 Haque Z. This is an open-access article distributed under the terms of the Creative Commons Attribution License, which permits unrestricted use, distribution, and reproduction in any medium, provided the original author and source are credited. 